\title{
Effects of exogenous application of polyamines on wheat anther cultures
}

\author{
Amina Redha $\cdot$ Patrice Suleman
}

Received: 12 May 2010/Accepted: 26 October 2010/Published online: 19 November 2010

(C) The Author(s) 2010. This article is published with open access at Springerlink.com

\begin{abstract}
Androgenesis of wheat genotypes was evaluated by pretreating anthers or embryo-like structures (ELS) with polyamines. Anthers of the genotype DH were pretreated with different concentrations of putrescine, spermidine, and spermine for 1,3 , and $6 \mathrm{~h}$, and those of drought-tolerant International Center for Agricultural Research in the Dry Areas (ICARDA) wheat accessions were treated for 1 and $3 \mathrm{~h}$. ELS of two genotypes were also treated for 30 and $60 \mathrm{~min}$ with the same polyamines and evaluated for green plant regeneration. The pretreatment of anthers with polyamines enhanced the development of ELS in all genotypes. The formation of ELS varied significantly with genotype. Pretreated anthers showed that four treatments improved significantly green plant regeneration with the genotype ICR 17 . However, two treatments (1 mM putrescine or spermine for $1 \mathrm{~h}$ ) significantly improved green plant regeneration per 100 ELS of only two ICARDA genotypes. ELS treated with polyamines for $30 \mathrm{~min}$ were greener and formed more adventitious roots. The chloroplasts of these greener ELS examined with a transmission electron microscope had agranal to grana thylakoids, while those of the control had plastids with mostly starch globules. Although exogenous application of polyamines to anthers improved the production of ELS and green plants, the effects of putrescine, spermidine, and spermine was dependent on genotype and the duration of pretreatment of anthers with the polyamines.
\end{abstract}

A. Redha $(\bowtie) \cdot$ P. Suleman

Department of Biological Sciences, Faculty of Science, Kuwait

University, P.O. Box 5969, Safat 13060, Kuwait

e-mail: aminaredha@gmail.com; a.redha@ku.edu.kw
Keywords Androgenesis - Chloroplast - Embryogenesis . Haploid · Plant regeneration · Triticum aestivum

$\begin{array}{ll}\text { Abbreviations } \\ \text { ELS } & \text { Embryo-like structures } \\ \text { GRP } & \text { Green regenerated plants } \\ \text { PAs } & \text { Polyamines } \\ \text { put } & \text { Putrescine } \\ \text { spd } & \text { Spermidine } \\ \text { spm } & \text { Spermine }\end{array}$

\section{Introduction}

The production of doubled haploid (DH) plants is valuable in plant biotechnology because it enables breeders to obtain homozygous lines or plants directly from hybrid individuals (Bajaj 1990; Teparkum and Veilleux 1998). Androgenesis can potentially produce a large number of doubled haploid plants due to the high number of microspores per anther. However, it is still necessary to improve the application of this technique, because many wheat cultivars of agronomic importance show very low or no response to androgenetic induction. The main factors that hinder the application of anther and microspore cultures are the low rates of embryogenesis and the high frequency of albinism among regenerated plants. Conventionally, varying sugars, auxin, and/or cytokinin in the culture medium yielded variable results in a number of crops, including wheat (Navarro-Alvarez et al. 1994; Wojnarowiez et al. 2004). However, manipulating conventional methods still remains the major approach to maximize the production of green plants. 
Polyamines (PAs) are naturally occurring, low molecular weight, polycationic, aliphatic nitrogenous compounds present in all cells. Polyamines are involved in a number of plant physiological processes such as morphogenesis, flower initiation, root growth, pollen viability, and biotic and abiotic stress responses (Bais and Ravishankar 2002; Bouchereau et al. 1999; Martin-Tanguy 2001). They are involved in plant nutrition in cultured tissues and are viewed as plant growth regulators or secondary hormonal messengers (Bais and Ravishankar 2002; Kakkar et al. 2000). In most plants, the levels of PAs are significantly greater than those of plant hormones. Several reports have shown the involvement of PAs in lateral and adventitious root formation (Couée et al. 2004). Anti-senescence or greening effect of PAs has also been reported in freshly isolated oat protoplasts (Altman et al. 1977) and studies with spermine and spermidine showed the retention of chlorophyll and the stabilization of thylakoid membranes (Besford et al. 1993; Tiburcio et al. 1994).

Exogenous PAs in culture medium induced in vitro organogenesis, and somatic and gametic embryogenesis in many plant species (Bertoldi et al. 2004; Kevers et al. 2002; Rajesh et al. 2003). In culture medium, PAs have been shown to increase the number of gynogenic embryos in Allium cepa L. (Martínez et al. 2000), androgenic embryos in potato (Tiainen 1992), in some Indian wheat cultivars (Rajyalakshmi et al. 1995), and in cucumber (Ashok Kumar et al. 2004). However, rice culture lost regeneration capacity with increasing age (Bajaj and Rajam 1995). The application of putrescine to barley and oat anthers delayed senescence of cultured anthers, and increased embryogenesis and plant regeneration in some recalcitrant genotypes (Cho and Kasha 1992; Kelley et al. 2002). Laukkanen and Sarjala (1997) showed that the exogenous application of PAs affected the metabolism of pine callus but did not prevent senescence. In embryogenesis of Solanum melongena hypocotyl segments, putrescine increased at maturity (Sharma and Rajam 1995), but in Camellia, both soluble and conjugated spermidine increase during the development of globular embryo (Pedroso et al. 1997).

In anther and microspore culture, the type of pretreatment and the carbohydrate used in culture medium are factors that affect barley and wheat androgenesis (Cistué and Kasha 2006; Devaux and Kasha 2009; Redha and Talaat 2008). In green plant regeneration, however, osmotic potential and the carbohydrate source also played significant roles in the switch from gametophytic to sporophytic phase of barley and wheat anthers. Most of the research conducted on the effects of polyamines were on somatic culture, and only a few investigated the influence of PAs on gametic embryogenesis (Martínez et al. 2000). Based on the various roles or functions of PAs and the limited studies on the effect of PAs in androgenesis, particularly in wheat, we hypothesized that the application of PAs to anthers in the initial phase of wheat androgenesis and/or to embryo-like structures (ELS) could influence green plant regeneration or chloroplast development, thus, enhancing the greening of regenerated plants.

The objective of this study was, therefore, to evaluate the effects of putrescine (put), spermidine (spd), and spermine (spm) as pretreatments of anthers or in the initial phase of wheat anther culture on ELS and regeneration of green plants.

\section{Materials and methods}

\section{Planting material}

Seeds of donor plants (DH, ICR 1, ICR 4, ICR 17, ICR 33, and ICR 39) were germinated at room temperature on moistened germination paper (Anchor paper \#38, St. Paul, Minnesota, USA). After 7 days, seedlings were transferred to pots $(10 \mathrm{~cm}$ in diameter) containing peat moss and placed in growth chambers at $18 \pm 1{ }^{\circ} \mathrm{C}$, under 16 -h photoperiod, and $290-310 \mu \mathrm{mol} \mathrm{m}{ }^{-2} \mathrm{~s}^{-1}$ light intensity. After 3 weeks, the plants were transferred to $15-\mathrm{cm}$-diameter pots. The actively growing plants were fertilized every fortnight with a complete and balanced fertilizer until flowering stage. Spikes were collected when most of the microspores were at mid- to late-uninucleate stage (Schmid 1990). The developmental stage of microspores was determined using acetocarmine stain. Developed tillers were selected and kept at $4^{\circ} \mathrm{C}$ for $7-10$ days.

\section{Anther culture}

The media used in anther culture were liquid anther induction medium (AM), embryo medium (EM), and plant regeneration medium (PM) (Schmid 1990). Phytagel $\left(3 \mathrm{gl}^{-1}\right)$ was added to the EM and PM media. Donor spikes were sterilized in $70 \%$ ethanol for $1 \mathrm{~min}$, and the anthers were dissected from flowers as described previously (Redha et al. 1998), and then plated in $60 \times 15$-mm Petri dishes containing $10 \mathrm{ml}$ of liquid anther induction medium. The number of replicates was ten per treatment, with 36 anthers in each Petri dish. Anthers were incubated in the dark at $28^{\circ} \mathrm{C}$ for 7 weeks. ELS produced were counted and transferred to the $\mathrm{PM}$ at $27^{\circ} \mathrm{C}$ at a photoperiod of $16 \mathrm{~h}$ and light intensity of $55 \mu \mathrm{mol} \mathrm{m}{ }^{-2} \mathrm{~s}^{-1}$. The criteria used to determine ELS was described by Büter et al. (1991). An ELS structure comprised of callus and/or embryo. Embryos readily stained in acetocarmine squashed preparation, while callus cell consisted of thick-wall parenchymatous cells with translucent or faintly stained cytoplasm. Young 
embryos consisted of isodiametric, meristematic cells with intensely stained nucleus and cytoplasm (Shumann 1990). After 4 weeks, regenerated green plants with well-developed roots and shoots were recorded and transferred to peat moss for further development.

Screening of genotypes for green plant regeneration

A total of 50 plant accession genotypes provided by the International Center for Agricultural Research in the Dry Areas (ICARDA), Aleppo, Syria, were screened for androgenetic performance with respect to the formation of ELS and green plant regeneration capacity. These genotypes were selected for their tolerance to drought conditions. The genotype, DH83Z118.32 (DH), provided by the Swiss Federal Institute of Technology, ETH, Zurich, was included for its high androgenetic response. Donor plants were grown and anthers cultured as described above.

Pretreatments of anthers with PAs

Anthers of the genotype DH were pretreated with put, spd, and spm alone at $1 \mathrm{mM}$ of each PA or $0.5+0.5 \mathrm{mM}$ combinations of each of the three PAs. The durations of the pretreatments were 1,3 , and $6 \mathrm{~h}$. The two best pretreatment periods were used in the anther culture of ICARDA genotypes. Anthers of the genotypes ICR 1, ICR 4, ICR 17, ICR 33, and ICR 39 were pretreated with put, spd, and spm alone at $1 \mathrm{mM}$ or in combinations of two of the three PAs at $0.5 \mathrm{mM}$. The durations of pretreatments were 1 and $3 \mathrm{~h}$, determined in a previous test using DH genotype, after which anthers were placed in AM containing sucrose (0.29 M).

\section{Treatment of ELS with PAs}

The ELS of two genotypes, ICR 4 (recalcitrant in terms of GRP/100 ELS produced) and ICR 39 (moderate response), were treated with PAs for 30 and $60 \mathrm{~min}$. PA treatments were with $1 \mathrm{mM}$ of put, spd, spm, and $0.5 \mathrm{mM}$ mixtures of PAs.

\section{Microscopy}

ELS tissues obtained were randomly sampled for transmission electron microscopy (TEM). Tissues were fixed overnight in $2.5 \%$ glutaraldehyde in $0.1 \mathrm{M}$ sodium cacodylate buffer ( $\mathrm{pH} 7.4)$, washed three times with cacodylate buffer, and post-fixed in $1.0 \%$ osmium tetroxide in the same buffer. The samples were dehydrated in a graded concentration of ethanol and embedded in epoxy resin. Semi-thin sections were cut and stained with toluidine blue and examined under a light microscope. Ultrathin sections were cut using an ultramicrotome (Leica Ultracut UCT) and stained with uranyl acetate, followed by lead citrate. The stained sections were examined in a transmission electron microscope (JEOL JEM-1200EX II). Micrographs were taken at $80 \mathrm{kV}$ on Kodak 4489 ESTAR thick-base photographic EM film.

Experimental design and data analysis

The experiment was designed to determine the influence of PAs on wheat genotypes. Firstly, 50 wheat accession genotypes were evaluated as described earlier to determine androgenesis response. Then, five genotypes were selected for the pretreatment of anthers with PAs. The DH genotype was used as a standard and the anthers were pretreated for 1,3 , and $6 \mathrm{~h}$ to determine how long anthers should be pretreated with PAs to improve plant regeneration. Then, anthers of five ICARDA genotypes were pretreated with $1.0 \mathrm{mM}$ of putrescine, spermidine, and spermine, and $0.5 \mathrm{mM}$ mixtures of each PA. Two genotypes (i.e., one recalcitrant and the other moderate in response with respect to GRP/100 anthers) were selected from the five and their ELS were pretreated with PAs. The effects of PAs on the genotype response was evaluated on the basis of ELS produced and green plant regeneration. ELS were recorded per 100 anthers (ELS/100 anthers), as well as green regenerated plants (GRP/100 anthers or ELS) (Broughton 2008; Büter et al. 1991; Redha et al. 2000). Each experiment was repeated three times. The data were pooled and subjected to analysis of variance (ANOVA), and the means were separated according to Fisher's protected least significant difference (LSD) using MSTAT-C. Data in percentages were arcsine transformed prior to analysis.

\section{Results}

Screening of genotypes

The androgenetic response of the 50 ICARDA genotypes showed significant differences with respect to ELS and GRP production among genotypes. Twenty-five genotypes formed less than $10 \%$ ELS (genotypes not listed, Table 1), including ICR 35, which did not produce any ELS. Approximately $40 \%$ of anthers of the genotypes ICR 4, ICR 5, ICR 17, ICR 18, ICR 36, and ICR 44 developed ELS, but most of these ELS differentiated into albino plants. Six genotypes (ICR 6, ICR 32, ICR 34, ICR 41, ICR 22 , and ICR 2) regenerated 9-20\% green plants from their ELS (Table 1). Generally, albinism was a problem with all genotypes; at least $60 \%$ of all ELS of the genotypes developed albino plants. 
Table 1 The androgenic response of ICARDA genotypes with respect to ELS and GRP formation

\begin{tabular}{|c|c|c|c|c|c|}
\hline \multicolumn{3}{|l|}{ Embryogenesis } & \multicolumn{3}{|c|}{ Green plant regeneration } \\
\hline No. of genotypes ${ }^{a}$ & ICARDA wheat accession number ${ }^{b}$ & $\%$ ELS & No. of genotypes ${ }^{\mathrm{a}}$ & ICARDA wheat accession number ${ }^{b}$ & $\%$ GRP \\
\hline 25 & N.L. & $0-10$ & 33 & N.L. & $0-4$ \\
\hline 12 & N.L. & $11-20$ & 11 & N.L. & $5-8$ \\
\hline 7 & ICR $1,13,33,38,39,46,49$ & $21-30$ & 4 & ICR $6,32,34,41$ & $9-12$ \\
\hline 0 & 0 & $31-40$ & 1 & ICR 22 & $13-16$ \\
\hline 6 & ICR $4,5,17,18,36,44$ & $41-60$ & 1 & ICR 2 & 17-20 \\
\hline
\end{tabular}

N.L. Genotypes not listed

a Represents the number of genotypes that produced ELS and GRP

b Shows the list of genotypes that produced ELS and GRP

Effect of PAs on anthers of DH genotype

The effects of PAs on DH anthers are presented in Figs. 1, 2 , and 3. Androgenic response was within 3-4 weeks for all treatments. Treatment differences were significant for GRP/100 anthers and GRP/100 ELS at $P=0.05$. The 1-h treatment showed that $1 \mathrm{mM}$ spm enhanced the formation of GRP/100 ELS (Fig. 1). There was no significant difference between the control and $1 \mathrm{mM}$ spd and $0.5 \mathrm{mM}$ (put + spd) with respect to GRP/100 ELS. Anther culture showed that spd and spm at $1 \mathrm{mM}$ enhanced the production of green plants in comparison to the control. All other PA treatments for $1 \mathrm{~h}$ yielded significantly fewer GRP/100 anthers. The 3-h treatments did not improve the formation of GRP/100 anthers, while $0.5 \mathrm{mM}$ (put + spd) only

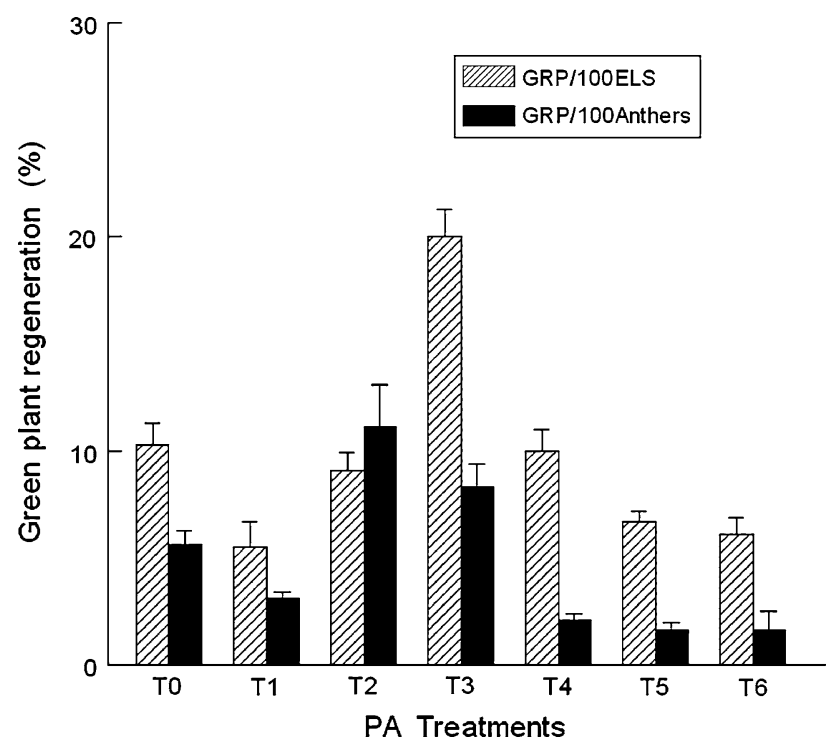

Fig. 1 The effect of PAs applied to DH anthers for $1 \mathrm{~h}$. Treatment abbreviations: $\mathrm{T} 0=$ control; $\mathrm{T} 1=1 \mathrm{mM}$ putrescine; $\mathrm{T} 2=1 \mathrm{mM}$ spermidine; $\mathrm{T} 3=1 \mathrm{mM}$ spermine; $\mathrm{T} 4=0.5 \mathrm{mM}$ (putrescine + spermidine); T5 $=0.5 \mathrm{mM}$ (putrescine + spermine); and T6 $=0.5 \mathrm{mM}$ (spermidine + spermine). The bars represent the standard error of the mean

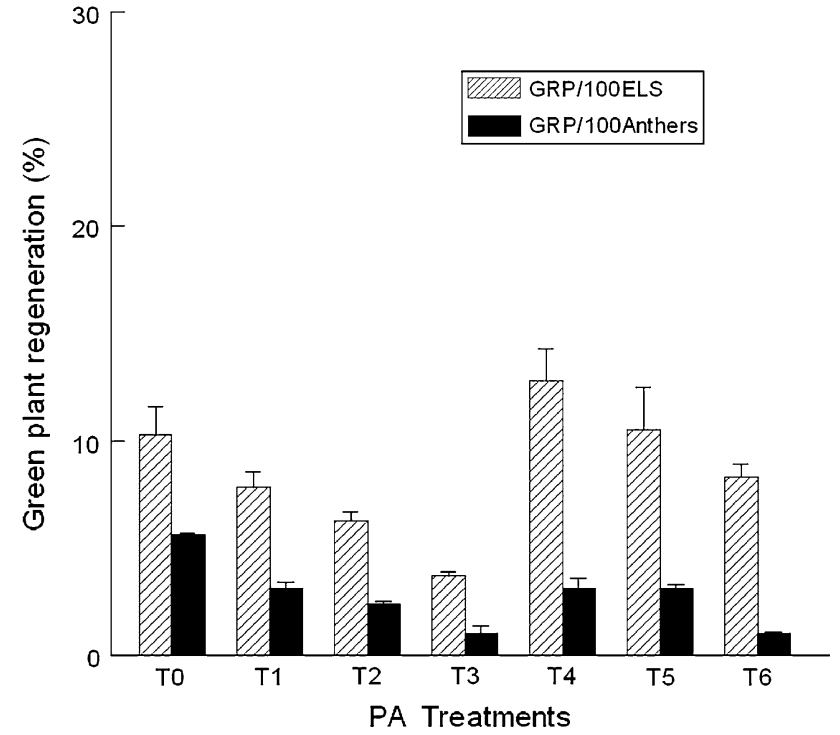

Fig. 2 The effect of PAs applied to DH anthers for $3 \mathrm{~h}$. Treatment abbreviations: $\mathrm{T} 0=$ control; $\mathrm{T} 1=1 \mathrm{mM}$ putrescine; $\mathrm{T} 2=1 \mathrm{mM}$ spermidine; $\mathrm{T} 3=1 \mathrm{mM}$ spermine; $\mathrm{T} 4=0.5 \mathrm{mM}$ (putrescine + spermidine); $\mathrm{T} 5=0.5 \mathrm{mM}$ (putrescine + spermine); and $\mathrm{T} 6=0.5 \mathrm{mM}$ (spermidine + spermine). The bars represent the standard error of the mean

improved the development of GRP/100 ELS (Fig. 2). For 6-h treatments, $1 \mathrm{mM}$ spm and $0.5 \mathrm{mM}$ (put $+\mathrm{spm}$ ) produced a significantly higher number of GRP/100 ELS (Fig. 3). The green plants produced per 100 anthers by all treatments were significantly less than the control.

Effect of PAs on anthers of ICARDA accession genotypes

Tables 2, 3, and 4 show the effects of PA treatments on the anthers of five selected ICARDA genotypes. The selection was based on the results of the screening test where the genotypes showed at least $20 \%$ ELS production or about $20 \%$ GRP. The effects of the treatments were variable for the genotypes. Compared to the controls, most of the PA 


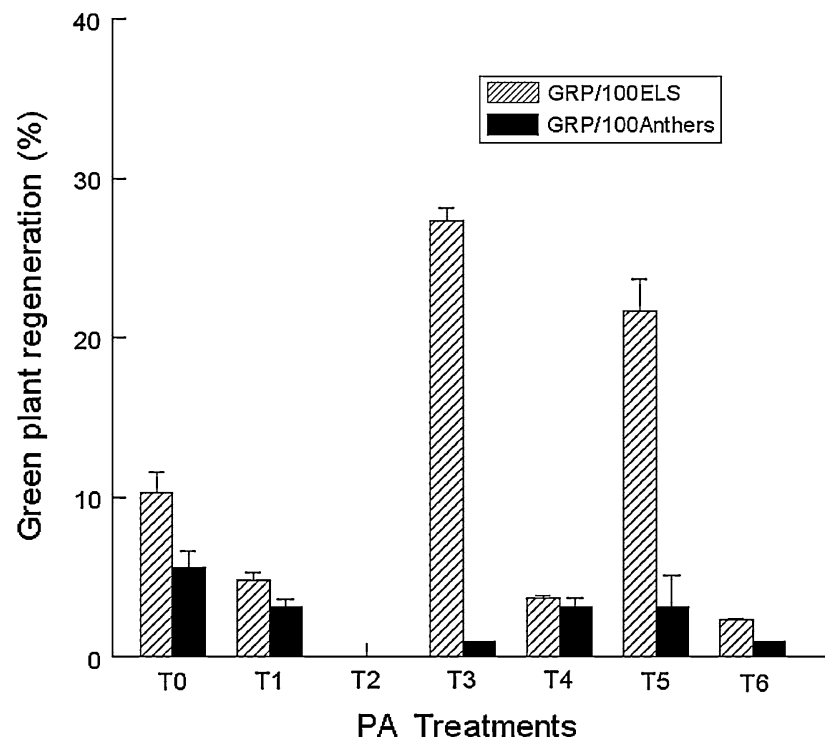

Fig. 3 The effect of PAs applied to DH anthers for $6 \mathrm{~h}$. Treatment abbreviations: $\mathrm{T} 0=$ control; $\mathrm{T} 1=1 \mathrm{mM}$ putrescine; $\mathrm{T} 2=1 \mathrm{mM}$ spermidine; $\mathrm{T} 3=1 \mathrm{mM}$ spermine; $\mathrm{T} 4=0.5 \mathrm{mM}$ (putrescine + spermidine); $\mathrm{T} 5=0.5 \mathrm{mM}$ (putrescine + spermine); and $\mathrm{T} 6=0.5 \mathrm{mM}$ (spermidine + spermine). The bars represent the standard error of the mean

treatments improved the production of ELS/100 anthers for all of the genotypes (Table 2). spm at $1 \mathrm{mM}$ for $3 \mathrm{~h}$ enhanced ELS/100 anthers in ICR 4 and ICR 33. Other treatments that showed significant improvement in ELS/ 100 anthers were $1 \mathrm{mM}$ put for $3 \mathrm{~h}$ in ICR $1,0.5 \mathrm{mM}$ $($ put + spm) for $3 \mathrm{~h}$ in ICR 17 , and $0.5 \mathrm{mM}$ (put + spd) for $1 \mathrm{~h}$ in ICR 39 .

Generally, 4 out of the 5 ICARDA genotypes showed improvement in the GRP formation/100 ELS, except for
ICR 33 (Table 3). There were no significant differences between the treatments for ICR 1 and ICR 4 with respect GRP/100 ELS. A significant difference in PA treatments was observed in the genotypes ICR 17 and ICR 39. The best treatments for these two genotypes were $1 \mathrm{mM}$ spm for $1 \mathrm{~h}$ and $1 \mathrm{mM}$ put for $1 \mathrm{~h}$, respectively.

\section{Effect of PAs on ELS of ICR 4 and ICR 39}

ELS of ICR 4 treated with $1.0 \mathrm{mM}$ put and spd, and those of ICR 39 treated with $0.5 \mathrm{mM}$ (put $+\mathrm{spm}$ ) for $30 \mathrm{~min}$ produced slightly larger ELS and numerous adventitious roots compared to the control (Fig. 4a). In general, adventitious root production was enhanced with the combined PA treatments (data not shown). Treatment with put $+\mathrm{spm}$ at $0.5 \mathrm{mM}$ for 30 min produced the most greenish ELS in genotype ICR 39 (Fig. 4a). All ELS treated with PAs for $60 \mathrm{~min}$ showed reduction in the growth and root proliferation (Fig. $4 \mathrm{~b}$ ). The only treatment that produced green plants (both roots and green shoot) in ICR 4 was $0.5 \mathrm{mM}(\mathrm{spd}+\mathrm{spm})$ after treatment for $30 \mathrm{~min}$ (Fig. $4 \mathrm{c}$ ), but the same treatment produced only albino plants with ICR 39.

\section{Microscopy}

Microscopy showed that the initial stage in the formation of ELS of both treated and untreated anthers was characterized by the formation of irregular cells, some of which appeared highly vacuolated. As the cells of the ELS from untreated anthers continued to proliferate, they accumulated mostly plastids with starch globules (Fig. 5a). The starch globules were depleted as the cells aged. put and

Table 2 The effect of PAs on the production of ELS/100 anthers in ICARDA wheat genotypes

\begin{tabular}{|c|c|c|c|c|c|}
\hline Treatments & ICR 1 & ICR 4 & ICR 17 & ICR 33 & ICR 39 \\
\hline Control & $60.2 \mathrm{f}$ & $46.1 \mathrm{~d}$ & $38.7 \mathrm{e}$ & $19.7 \mathrm{c}$ & $10.6 \mathrm{c}$ \\
\hline $1 \mathrm{mM}$ put for $1 \mathrm{~h}$ & $67.5 \mathrm{f}$ & $46.8 \mathrm{~d}$ & $36.1 \mathrm{e}$ & $25.2 \mathrm{bc}$ & $17.6 \mathrm{~b}$ \\
\hline $1 \mathrm{mM}$ spd for $1 \mathrm{~h}$ & 69.4 ef & $58.2 \mathrm{c}$ & $21.3 \mathrm{f}$ & $40.6 \mathrm{a}$ & $14.2 \mathrm{c}$ \\
\hline $1 \mathrm{mM}$ spm for $1 \mathrm{~h}$ & $47.5 \mathrm{~g}$ & $42.8 \mathrm{~d}$ & $26.6 \mathrm{f}$ & $27.9 \mathrm{~b}$ & $21.6 \mathrm{ab}$ \\
\hline $0.5 \mathrm{mM}$ put $+0.5 \mathrm{mM}$ spd for $1 \mathrm{~h}$ & $63.9 \mathrm{f}$ & $36.5 \mathrm{e}$ & $51.7 \mathrm{~cd}$ & $28.6 \mathrm{~b}$ & $24.8 \mathrm{a}$ \\
\hline $0.5 \mathrm{mM}$ put $+0.5 \mathrm{mM} \mathrm{spm}$ for $1 \mathrm{~h}$ & $114.1 \mathrm{~b}$ & $60.4 \mathrm{~b}$ & $48.9 \mathrm{~d}$ & $29.8 \mathrm{~b}$ & $23.6 \mathrm{a}$ \\
\hline $0.5 \mathrm{mM} \mathrm{spd}+0.5 \mathrm{mM} \mathrm{spm}$ for $1 \mathrm{~h}$ & $105.8 \mathrm{c}$ & $47.2 \mathrm{~d}$ & $63.4 \mathrm{~b}$ & $28.0 \mathrm{~b}$ & $20.4 \mathrm{ab}$ \\
\hline $1 \mathrm{mM}$ put for $3 \mathrm{~h}$ & $125.6 \mathrm{a}$ & $53.2 \mathrm{c}$ & $56.6 \mathrm{c}$ & $22.8 \mathrm{c}$ & $17.3 \mathrm{~b}$ \\
\hline $1 \mathrm{mM}$ spd for $3 \mathrm{~h}$ & $72.0 \mathrm{e}$ & $50.3 \mathrm{c}$ & $38.2 \mathrm{e}$ & $24.9 \mathrm{bc}$ & $23.8 \mathrm{a}$ \\
\hline $1 \mathrm{mM}$ spm for $3 \mathrm{~h}$ & $95.5 \mathrm{~d}$ & $70.8 \mathrm{a}$ & $62.2 \mathrm{~b}$ & $47.6 \mathrm{a}$ & $15.6 \mathrm{~b}$ \\
\hline $0.5 \mathrm{mM}$ put $+0.5 \mathrm{mM}$ spd for $3 \mathrm{~h}$ & $63.9 \mathrm{f}$ & $49.7 \mathrm{~cd}$ & $65.9 \mathrm{~b}$ & $43.1 \mathrm{a}$ & $11.1 \mathrm{c}$ \\
\hline $0.5 \mathrm{mM}$ put $+0.5 \mathrm{mM} \mathrm{spm}$ for $3 \mathrm{~h}$ & $93.4 \mathrm{~d}$ & $53.7 \mathrm{c}$ & $76.1 \mathrm{a}$ & $29.5 \mathrm{~b}$ & $17.7 \mathrm{~b}$ \\
\hline $0.5 \mathrm{mM} \mathrm{spd}+0.5 \mathrm{mM} \mathrm{spm}$ for $3 \mathrm{~h}$ & $66.2 \mathrm{f}$ & 38.9 e & $38.7 \mathrm{e}$ & $21.3 \mathrm{c}$ & $12.1 \mathrm{c}$ \\
\hline
\end{tabular}

PAs polyamines; ELS embryo-like structures; put putrescine; spd spermidine; spm spermine

Means followed by the same letter within a column are not significantly different at $P \leq 0.05$ as determined by LSD 
Table 3 The effect of PAs on the production of GRP/100 ELS in ICARDA wheat genotypes

\begin{tabular}{|c|c|c|c|c|c|}
\hline Treatments & ICR 1 & ICR 4 & ICR 17 & ICR 33 & ICR 39 \\
\hline Control & $0.3 *$ & $0.3 *$ & $15.5 \mathrm{a}$ & $9.2 \mathrm{a}$ & $3.5 \mathrm{~b}$ \\
\hline $1 \mathrm{mM}$ put for $1 \mathrm{~h}$ & 0.3 & 0.3 & $9.5 \mathrm{~b}$ & $2.5 \mathrm{~b}$ & $7.4 \mathrm{a}$ \\
\hline $1 \mathrm{mM}$ spd for $1 \mathrm{~h}$ & 1.8 & 0.7 & $3.7 \mathrm{~d}$ & $2.7 \mathrm{~b}$ & $0.0 \mathrm{c}$ \\
\hline $1 \mathrm{mM} \mathrm{spm}$ for $1 \mathrm{~h}$ & 2.0 & 0.7 & $18.1 \mathrm{a}$ & $3.3 \mathrm{~b}$ & $0.9 \mathrm{c}$ \\
\hline $0.5 \mathrm{mM}$ put $+0.5 \mathrm{mM}$ spd for $1 \mathrm{~h}$ & 0.8 & 0.0 & $10.0 \mathrm{~b}$ & $1.1 \mathrm{~b}$ & $1.4 \mathrm{c}$ \\
\hline $0.5 \mathrm{mM}$ put $+0.5 \mathrm{mM}$ spm for $1 \mathrm{~h}$ & 1.2 & 0.0 & $5.7 \mathrm{~d}$ & $3.1 \mathrm{~b}$ & $2.9 \mathrm{bc}$ \\
\hline $0.5 \mathrm{mM} \mathrm{spd}+0.5 \mathrm{mM}$ spm for $1 \mathrm{~h}$ & 0.4 & 0.3 & $12.7 \mathrm{ab}$ & $2.5 \mathrm{~b}$ & $1.0 \mathrm{c}$ \\
\hline $1 \mathrm{mM}$ put for $3 \mathrm{~h}$ & 2.7 & 0.5 & $12.5 \mathrm{ab}$ & $1.7 \mathrm{~b}$ & $2.3 \mathrm{bc}$ \\
\hline $1 \mathrm{mM}$ spd for $3 \mathrm{~h}$ & 0 & 0.0 & $11.1 \mathrm{~b}$ & $1.2 \mathrm{~b}$ & $0.0 \mathrm{c}$ \\
\hline $1 \mathrm{mM} \mathrm{spm}$ for $3 \mathrm{~h}$ & 0 & 0.0 & $11.4 \mathrm{~b}$ & $2.0 \mathrm{~b}$ & $3.6 \mathrm{~b}$ \\
\hline $0.5 \mathrm{mM}$ put $+0.5 \mathrm{mM}$ spd for $3 \mathrm{~h}$ & 1.2 & 0.0 & $5.8 \mathrm{~d}$ & $3.9 \mathrm{~b}$ & $5.4 \mathrm{ab}$ \\
\hline $0.5 \mathrm{mM}$ put $+0.5 \mathrm{mM} \mathrm{spm}$ for $3 \mathrm{~h}$ & 0.7 & 0.0 & $8.9 \mathrm{c}$ & $2.9 \mathrm{~b}$ & $0.9 \mathrm{c}$ \\
\hline $0.5 \mathrm{mM} \mathrm{spd}+0.5 \mathrm{mM}$ spm for $3 \mathrm{~h}$ & 1.8 & 0.0 & $9.0 \mathrm{c}$ & $1.5 \mathrm{~b}$ & $2.7 \mathrm{bc}$ \\
\hline
\end{tabular}

PAs polyamines; GRP green regenerated plants; $E L S$ embryo-like structures; put putrescine; spd spermidine; spm spermine

* Not significantly different

Means followed by the same letter within a column are not significantly different at $P \leq 0.05$ as determined by LSD

Table 4 The effect of PAs on the production of GRP/100 anthers in ICARDA wheat genotypes

\begin{tabular}{|c|c|c|c|c|c|}
\hline Treatments & ICR 1 & ICR 4 & ICR 17 & ICR 33 & ICR 39 \\
\hline Control & $0.2^{*}$ & $0.2 *$ & $6.0 \mathrm{~b}$ & $1.8^{*}$ & $0.4^{*}$ \\
\hline $1 \mathrm{mM}$ put for $1 \mathrm{~h}$ & 0.2 & 0.1 & $3.4 \mathrm{~d}$ & 0.6 & 1.3 \\
\hline $1 \mathrm{mM}$ spd for $1 \mathrm{~h}$ & 1.2 & 0.4 & $0.8 \mathrm{e}$ & 1.1 & 0.0 \\
\hline $1 \mathrm{mM} \mathrm{spm}$ for $1 \mathrm{~h}$ & 0.9 & 0.3 & $4.8 \mathrm{c}$ & 0.9 & 0.2 \\
\hline $0.5 \mathrm{mM}$ put $+0.5 \mathrm{mM}$ spd for $1 \mathrm{~h}$ & 0.5 & 0.0 & $5.1 \mathrm{~b}$ & 0.3 & 0.4 \\
\hline $0.5 \mathrm{mM}$ put $+0.5 \mathrm{mM}$ spm for $1 \mathrm{~h}$ & 1.4 & 0.0 & $2.8 \mathrm{e}$ & 0.9 & 0.7 \\
\hline $0.5 \mathrm{mM} \mathrm{spd}+0.5 \mathrm{mM}$ spm for $1 \mathrm{~h}$ & 0.4 & 0.1 & $8.0 \mathrm{a}$ & 0.7 & 0.2 \\
\hline $1 \mathrm{mM}$ put for $3 \mathrm{~h}$ & 3.3 & 0.3 & $7.1 \mathrm{a}$ & 0.4 & 0.4 \\
\hline $1 \mathrm{mM}$ spd for $3 \mathrm{~h}$ & 0 & 0.0 & $4.2 \mathrm{c}$ & 0.3 & 0.0 \\
\hline $1 \mathrm{mM} \mathrm{spm}$ for $3 \mathrm{~h}$ & 0 & 0.0 & $7.1 \mathrm{a}$ & 1.0 & 0.6 \\
\hline $0.5 \mathrm{mM}$ put $+0.5 \mathrm{mM}$ spd for $3 \mathrm{~h}$ & 0.7 & 0.0 & $3.9 \mathrm{c}$ & 1.7 & 0.6 \\
\hline $0.5 \mathrm{mM}$ put $+0.5 \mathrm{mM}$ spm for $3 \mathrm{~h}$ & 0.6 & 0.0 & $6.8 \mathrm{ab}$ & 0.9 & 0.2 \\
\hline $0.5 \mathrm{mM} \mathrm{spd}+0.5 \mathrm{mM}$ spm for $3 \mathrm{~h}$ & 1.2 & 0.0 & $3.4 \mathrm{~d}$ & 0.3 & 0.3 \\
\hline
\end{tabular}

$P A s$ polyamines; GRP green regenerated plants; put putrescine; spd spermidine; spm spermine

* Not significantly different

Means followed by the same letter within a column are not significantly different at $P \leq 0.05$ as determined by LSD

spd-treated anthers or ELS developed chloroplasts with thylakoid systems that were well organized into grana. The chloroplasts from put appeared to be well developed with plastoglobules with apparently no starch granules (Fig. 5b). spm treatment had more agranal-like chloroplasts with thylakoids that were not well organized as grana, or had few grana with a couple of starch grains (Fig. 5c). These chloroplasts (spm-treated) were not only slow in their development, but they appeared to be smaller in size compared to those from put and spd treatments. ELS treated with PAs also developed more meristemoids or centers of meristematic cells with dense cytoplasm. These meristemoids appeared to give rise mostly to adventitious roots.

\section{Discussion}

PAs are compounds involved in a number of developmental processes in plants and, although much research has been conducted on the effects of PAs on tissue culture, only a few researchers have studied their influence on gametic 

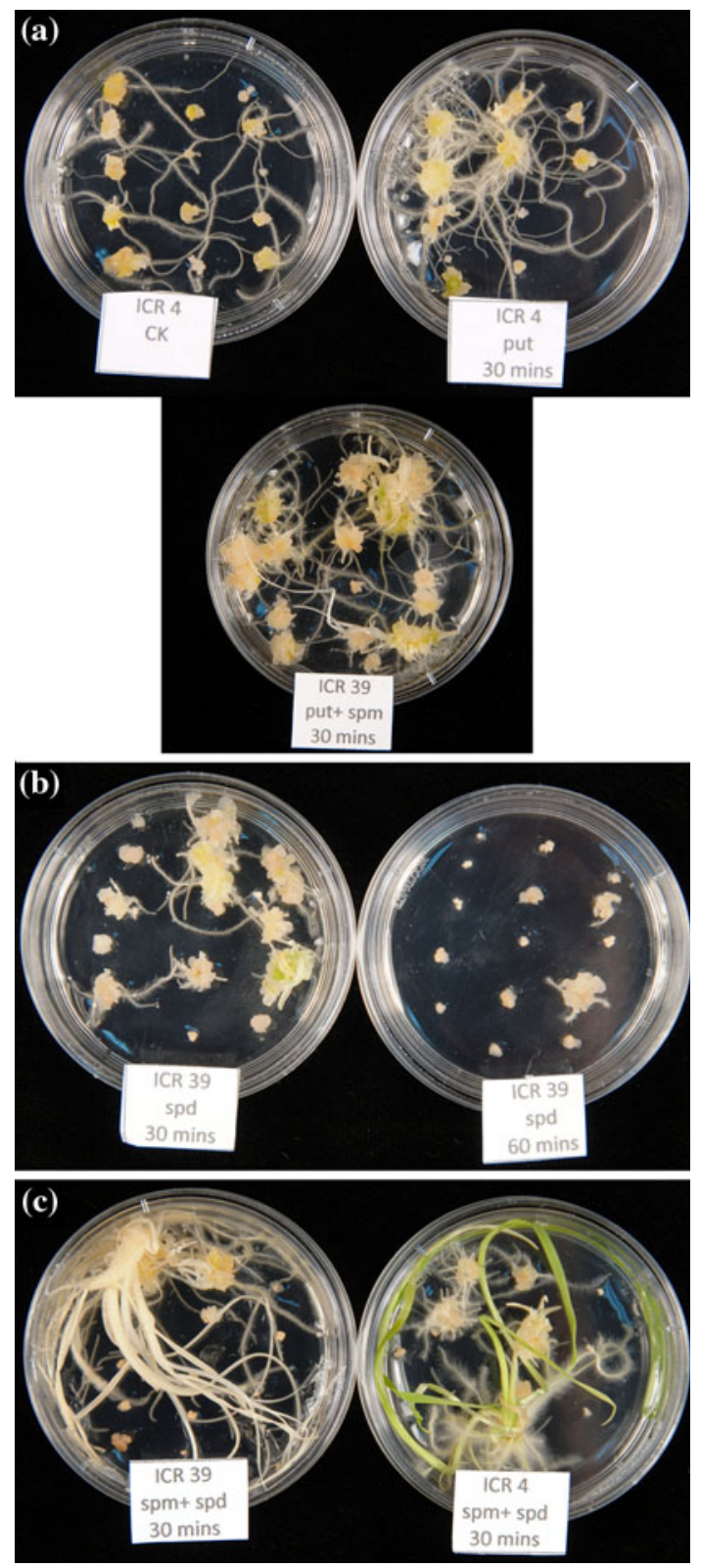

Fig. 4a-c The effect of PAs on ICARDA wheat genotypes. a The effect of $1 \mathrm{mM}$ putrescine (put) and $0.5 \mathrm{mM}$ (put $+\mathrm{spm}$ ) on ELS of ICR 4 and ICR 39 for $30 \mathrm{~min}$. $C K=$ control. b The effect of $1 \mathrm{mM}$ spermidine (spd) on ELS of ICR 39 wheat genotype for 30 and $60 \mathrm{~min}$. $\mathrm{c}$ The effect $0.5 \mathrm{mM}$ (spm $+\mathrm{spd}$ ) on ELS of ICR 39 and ICR 4 wheat genotypes for $30 \mathrm{~min}$. $s p m=$ spermine and $s p d$ $=$ spermidine

embryogenesis (Martínez et al. 2000). In this study, the effects of PAs on anthers and the duration of pretreatment showed that the ELS and GRP formation varied among genotypes. Exogenous application of PAs to anthers for $1 \mathrm{~h}$ appeared to exert a weak plant growth regulator-like effect on anthers with the formation of calli and regenerants having more adventitious roots. Shariatpanahi et al. (2006) reported similar observations in cultured wheat microspore, in which the medium was supplemented with $1 \mathrm{mgl}^{-1}$ 2,4-D plus $0.2 \mathrm{mgl}^{-1}$ kinetin. In this study, ELS or GRP/ 100 anthers was enhanced particularly with put, spd alone, or a combination of put, spd, or spm (Kelley et al. 2002; Meijer and Simmonds 1988; Phillips et al. 1987; Rajyalakshmi et al. 1995). Similar results were observed with the application of put to some recalcitrant barley (Cho and Kasha 1992), oat anther cultures (Kelley et al. 2002), and rice anther culture (Dewi and Purwoko 2008).

The production of ELS for some of the genotypes increased over 100-fold and exogenous application of the PAs to these ELS resulted in more root proliferation, greener ELS, and/or green plants. This study corroborates the observation of Couée et al. (2004), who reported the involvement of PAs in lateral and adventitious root formation. The greening or anti-senescence effects of PAs was also reported in freshly isolated oat protoplasts and rice anther culture (Altman et al. 1977; Dewi and Purwoko 2008), and studies with spm and spd showed the retention of chlorophyll and stabilization of thylakoid membranes (Besford et al. 1993; Tiburcio et al. 1994).

The greener ELS observed in this study was due to the development of agranal-like to normal chloroplasts in the undifferentiated ELS cells. In wheat androgenesis, this is the first report of this phenomenon of greening of ELS. This led to the speculation of the involvement of paternal inheritance of chloroplasts in the genotypes used in this study. Paternal inheritance of chloroplasts was observed in some crosses of agronomic crops such as Hordeum $\times$ Secale (Soliman et al. 1987), and chloroplast inheritance of this nature is mostly common in interspecific hybrids (Hansen et al. 2007).

The effects of PAs in this study was not generalized in the genotypes, since some of the genotypes still showed no improvement in the development of ELS or GRP/100 anthers. During androgenesis of Triticum aestivum (Bothma and Duberry 1991), Nicotiana tabacum, and Datura innoxia (Villanueva et al. 1985), put and spd were found to be the major PAs, and could be relevant in anther culture. Recent studies with wheat have also shown genetic variability in androgenic traits with respect to embryo induction and plant regeneration (Liu et al. 2002; Zheng 2003).

In summary, this study showed that low concentrations of put or together with spd or spm could be used in androgenesis of some recalcitrant wheat genotypes to improve ELS induction and regeneration of green plants. Green plant regeneration was enhanced when anthers or ELS at the initial stage of development were pretreated with put, spd, and spm for 1-3 h. The application of PAs appeared to improve androgenesis by increasing cell proliferation of cultured anthers and ELS production that regenerated to green plants. This study also indicated that the treatment of anthers at the induction phase with PAs is 


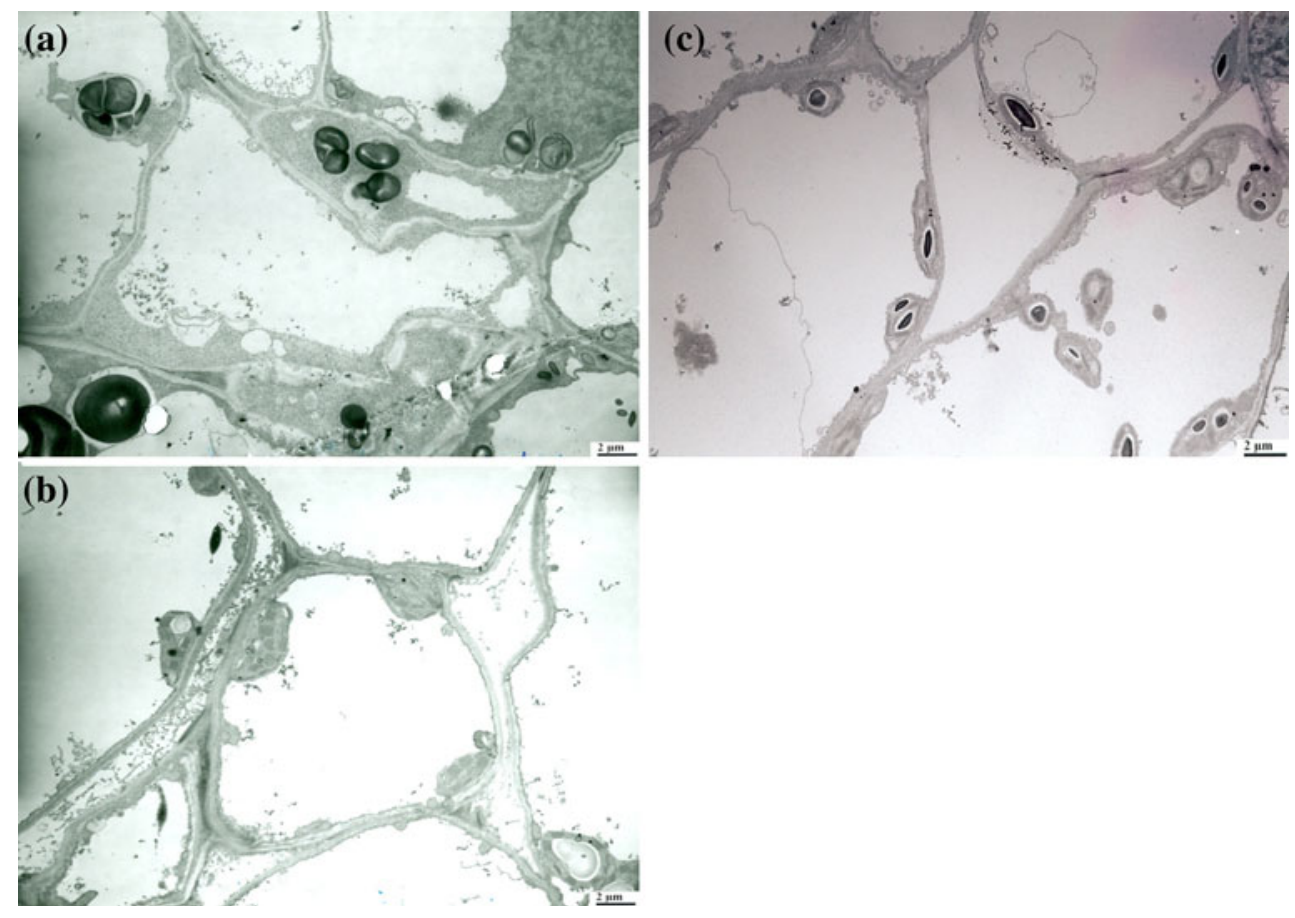

Fig. 5 Electron micrographs of untreated and PA-treated ELS. a Cells of control treatment with plastids of starch globules. b Cells of ELS from putrescine treatment with well-developed chloroplasts and plastoglobules. $\mathbf{c}$ Cells of ELS from spermine treatment with agranal-like chloroplasts

preferable to treating ELS, even in genotypes poor or recalcitrant in anther culture response.

Acknowledgments Funding for this project (no. SL04/06) was provided by the Research Administration of Kuwait University. We thank Cynthia A. Menezes for serving as the Research Assistant and the Electron Microscopy Unit of Kuwait University for their assistance with the transmission electron microscope (TEM) analysis.

Open Access This article is distributed under the terms of the Creative Commons Attribution Noncommercial License which permits any noncommercial use, distribution, and reproduction in any medium, provided the original author(s) and source are credited.

\section{References}

Altman A, Kaur-Sawhney R, Galston AW (1977) Stabilization of oat leaf protoplasts through polyamine-mediated inhibition of senescence. Plant Physiol 60:570-574

Ashok Kumar HG, Ravishankar BV, Murthy HN (2004) The influence of polyamines on androgenesis of Cucumis sativus $\mathrm{L}$. Eur J Hort Sci 69:201-205

Bais HP, Ravishankar GA (2002) Role of polyamines in the ontogeny of plants and their biotechnological applications. Plant Cell Tiss Organ Cult 69:1-34

Bajaj YPS (1990) In vitro production of haploids and their use in cell genetics and plant breeding. In: Bajaj YPS (ed) Biotechnology in agriculture and forestry, vol. 12. Haploids in crop improvement. Springer-Verlag, Berlin, Heidelberg, pp 3-49
Bajaj S, Rajam MV (1995) Efficient plant regeneration from longterm callus cultures of rice by spermidine. Plant Cell Rep 14: $717-720$

Bertoldi D, Tassoni A, Martinelli L, Bagni N (2004) Polyamines and somatic embryogenesis in two Vitis vinifera cultivars. Physiol Plant 120:657-666

Besford RT, Richardson CM, Campos JL, Tiburcio AF (1993) Effect of polyamines on stabilization of molecular complexes in thylakoid membranes of osmotically stressed oat leaves. Planta 189:201-206

Bothma C, Duberry IA (1991) The effect of polyamines on protein kinase activities of wheat (Triticum aestivum) L. anthers. Plant Growth Reg 10:363-375

Bouchereau A, Aziz A, Larher F, Martin-Tanguy J (1999) Polyamines and environmental challenges: recent development. Plant Sci 140:103-125

Broughton S (2008) Ovary co-culture improves embryo and green plant production in anther culture of Australian spring wheat (Triticum aestivum L.). Plant Cell Tiss Organ Cult 95:185-195

Büter B, Schmid JE, Stamp P (1991) Effects of L-proline and postplating temperature treatment on maize (Zea mays L.) anther culture. Plant Cell Rep 10:325-328

Cho UH, Kasha KJ (1992) Relationship of senescence to androgenesis in barley (Hordeum vulgare L. cv. Klages). J Plant Physiol 139:299-302

Cistué L, Kasha KJ (2006) Gametic embryogenesis in Triticum: a study of some critical factors in haploid (microspore) embryogenesis. In: Robinson DG (ed) Plant cell monographs: somatic embryogenesis, 2nd edn. Springer, Heidelberg, pp 321-342

Couée I, Hummel I, Sulmon C, Gouesbet G, El Armani A (2004) Involvement of polyamines in root development. Plant Cell Tiss Organ Cult 76:1-10 
Devaux P, Kasha KJ (2009) Overview of barley doubled haploid production. In: Touraev A, Forster BP, Jain SM (eds) Advances in haploid production in higher plants. Springer, Netherlands, pp 47-63

Dewi IS, Purwoko BS (2008) Role of polyamines in inhibition of ethylene biosynthesis and their effects on rice anther culture development. Indones J Agric Sci 9:60-67

Hansen AK, Escobar LK, Gilbert LE, Jansen RK (2007) Paternal, maternal, and biparental inheritance of the chloroplast genome in Passiflora (Passifloraceae): implications for phylogenetic studies. Am J Bot 94:42-46

Kakkar RK, Nagar PK, Ahuja PS, Rai VK (2000) Polyamines and plant morphogenesis. Biol Plant 43:1-11

Kelley RY, Zipf AE, Wesenberg DE, Sharma GC (2002) Putrescineenhanced somatic embryos and plant numbers from elite oat (Avena spp. L.) and reciprocal crosses. In Vitro Cell Dev Biol Plant 38:508-512

Kevers C, Gaspar T, Jacques D (2002) The beneficial role of different auxins and polyamines at successive stages of somatic embryo formation and development of Panax ginseng in vitro. Plant Cell Tiss Organ Cult 70:181-188

Laukkanen H, Sarjala T (1997) Effect of exogenous polyamines on Scots pine callus in vitro. J Plant Physiol 150:167-172

Liu W, Zheng MY, Polle EA, Konzak CF (2002) Highly efficient doubled-haploid production in wheat (Triticum aestivum L.) via induced microspore embryogenesis. Crop Sci 42:686-692

Martínez LE, Agüero CB, López ME, Galmarini CR (2000) Improvement of in vitro gynogenesis induction in onion (Allium cepa L.) using polyamines. Plant Sci 156:221-226

Martin-Tanguy J (2001) Metabolism and function of polyamines in plants: recent development (new approaches). Plant Growth Regul 34:135-148

Meijer EGM, Simmonds J (1988) Polyamine levels in relation to growth and somatic embryogenesis in tissue cultures of Medicago sativa L. J Exp Bot 39:787-794

Navarro-Alvarez W, Baenziger PS, Eskridge KM, Shelton DR, Gustafson VD, Hugo M (1994) Effect of sugars in wheat anther culture media. Plant Breed 112:53-62

Pedroso MC, Primikirios N, Roubelakis-Angelakis KA, Pais MS (1997) Free and conjugated polyamines in embryogenic and nonembryogenic leaf regions of Camellia leaves before and during direct somatic embryogenesis. Physiol Plant 101:213-219

Phillips R, Press MC, Eason A (1987) Polyamines in relation to cell division and xylogenesis in cultured explants of Helianthus tuberosus: lack of evidence for growth-regulatory action. J Exp Bot 38:164-172

Rajesh MK, Radha E, Karun A, Parthasarathy VA (2003) Plant regeneration from embryo-derived callus of oil palm - the effect of exogenous polyamines. Plant Cell Tiss Organ Cult 75:41-47

Rajyalakshmi K, Chowdhry CN, Maheshwari N, Maheshwari SC (1995) Anther culture response in some Indian wheat cultivars and the role of polyamines in induction of haploids. Phytomorphology 45:139-145
Redha A, Talaat A (2008) Improvement of green plant regeneration by manipulation of anther culture induction medium of hexaploid wheat. Plant Cell Tiss Organ Cult 92:141-146

Redha A, Attia T, Büter B, Stamp P, Schmid JE (1998) Single and combined effects of calchicine, L-proline and post inoculation low temperature on anther culture of wheat (Triticum aestivum L.). Plant Breeding 117:335-340

Redha A, Islam SMS, Büter B, Stamp P, Schmid JE (2000) The improvement in regenerated doubled haploids from anther culture of wheat by anther transfer. Plant Cell Tiss Organ Cult 63:167-172

Schmid JE (1990) In vitro production of haploids in Triticum spelta. In: Bajaj YPS (ed) Biotechnology in agriculture and forestry, vol 13: wheat. Springer-Verlag, Berlin, Heidelberg, pp 363-381

Shariatpanahi ME, Belogradova K, Hessamvaziri L, Heberle-Bors E, Touraev A (2006) Efficient embryogenesis and regeneration in freshly isolated and cultured wheat (Triticum aestivum L.) microspores without stress pretreatment. Plant Cell Rep 25(12): 1294-1299

Sharma P, Rajam MV (1995) Spatial and temporal changes in endogenous polyamine levels associated with somatic embryogenesis from different hypocotyl segments of eggplant (Solanum melongena L.). J Plant Physiol 146:658-664

Shumann G (1990) In vitro production of haploids in triticale. In: Bajaj YPS (ed) Biotechnology in agriculture and forestry, vol. 13: wheat. Springer-Verlag, Berlin, Heidelberg, pp 382-402

Soliman K, Fedak G, Allard RW (1987) Inheritance of organelle DNA in barley and Hordeum $\times$ Secale intergeneric hybrids. Genome 29:867-872

Teparkum S, Veilleux RE (1998) Indifference of potato anther culture to colchicine and genetic similarity among anther-derived monoploid regenerants determined by RAPD analysis. Plant Cell Tiss Organ Cult 53:49-58

Tiainen T (1992) The role of ethylene and reducing agents on anther culture response of tetraploid potato (Solanum tuberosum L.). Plant Cell Rep 10:604-607

Tiburcio AF, Besford RT, Capell T, Borrell A, Testillano PS, Risueño MC (1994) Mechanisms of polyamine action during senescence responses induced by osmotic stress. J Exp Bot 45:1789-1800

Villanueva VR, Mathivet V, Sangwan RS (1985) RNA, proteins and polyamines during gametophytic and androgenetic development of pollen in Nicotiana tabacum and Datura innoxia. Plant Growth Reg 3:293-307

Wojnarowiez G, Caredda S, Devaux P, Sangwan R, Clément C (2004) Barley anther culture: assessment of carbohydrate effects on embryo yield, green plant production and differential plastid development in relation with albinism. J Plant Physiol 161: $747-755$

Zheng MY (2003) Microspore culture in wheat (Triticum aestivum) doubled haploid production via induced embryogenesis. Plant Cell Tiss Organ Cult 73:213-230 